\title{
Economic Value Added (EVA) Disclosure Practices of Sri Lankan Listed Companies
}

\author{
P. M. C. Thilakerathne \\ Department of Accountancy, Faculty of Commerce \& Management Studies, University of Kelaniya, Kelaniya, Sri Lanka
}

\section{Email address:}

lal@kln.ac.lk

\section{To cite this article:}

P. M. C. Thilakerathne. Economic Value Added (EVA) Disclosure Practices of Sri Lankan Listed Companies. Journal of Finance and Accounting. Vol. 3, No. 5, 2015, pp. 117-127. doi: 10.11648/j.jfa.20150305.12

\begin{abstract}
Transparency, disclosures and information sharing with stakeholders, command a considerable degree of value to the accompanying financial statements of any corporate or business enterprise. Investors and stakeholders are increasingly looking at the performance of companies which they have invested their hard earned funds. To meet such expectations, good governed companies do adopt practices which add to enhance the value of financial statements and value to its readers. The ideas of free cash flow and the evaluation of business on a cash basis developed by Modiglaini and Miller (1961) were extended into the concept of the Economic Value Added (EVA) (Stewart and Stern 1971). The traditional financial performance measures have not presented the real shareholder value of an enterprise. Thus, the EVA is one of main evaluation criteria of companies' commitment with shareholder value maximization. In this context, this research investigated the EVA disclosures in the annual reports of Sri Lankan listed companies. Analyzing annual reports of Sri Lankan largest 85 listed companies over a period of 5 years from 2009 to 2013, the results indicated that 15 numbers of listed companies, as a percentage of 17.65 of the sample disclosed the EVA statement in their annual reports. The study further explored the industry composition, residential status, medium of disclosure, areas of EVA application and extent of EVA related computation prepared and disclosed by EVA reporting companies. Univariate analysis was used to identify the extent of EVA disclosures of listed companies in Sri Lanka and it was found that, existence of significant inconsistencies and irregularities in measurement of EVA and its major components of EVA reporting listed companies. The second part of the study explored that the corporate attributes such as back ground information and financial performance indicators of companies are influenced to the choice of EVA disclosure. Therefore, research performed a comparison of differences between EVA reporting and EVA non reporting listed companies on the basis of their background indicators and financial performance measures. Research employed the two independent sample t-tests to identify the factors influencing to EVA usage and disclosure choice of Sri Lankan listed companies in terms of company size, profitability, leverage etc. Research finds that the EVA usage and EVA disclosure choice of Sri Lankan companies are influenced by the company size, leverage and earnings potential. Further, the study recommends the importance of implementing EVA disclosures as a mandatory requirement for Sri Lankan listed companies.
\end{abstract}

Keywords: Economic Value Added, EVA Disclosures, Colombo Stock Exchange, EVA Disclosure Mediums, Financial Performance of Listed Companies

\section{Introduction}

Shareholder wealth maximization has become the emerging corporate paradigm in recent years. Shareholder returns decomposed into two parts that is dividends and capital appreciation. Once dividend signal passes to the market as a result of that naturally share prices of particular stocks move into the upward direction. The market value of stocks depends on number of factors. Company disclosures are used by various stakeholders to assess firm's current performance as well as to forecast the future as well. Complexity and the competiveness of business environment are increased dramatically and significantly. The need of creative leadership to handle the new developments in global business, technology, mergers and E-commerce and innovation are accelerated. Due to these developments in the business environment companies need more powerful and sophisticated financial and non financial indicators to measure the organizational performance. 
On the other hand corporate governance principles and practices command a considerable degree of value to the accompanying financial statements of any corporate or business enterprise. Investors and stockholders are also increasingly looking at quality of numbers rather than quantity. To meet such expectations, good governed companies do adopt practices which enhance the value of financial statements and value to the stakeholders. EVA as such increases the value of disclosures. Traditional performance measures of an enterprise such as Net Profit Margin, Return on Investment (ROI), Return on Equity (ROE), Return on Capital Employed (ROCE), Return on Total Assets (ROTA), Earnings per Share (EPS) and Price Earnings Ratio (P/E Ratio) have been criticized due to their inability to incorporate full cost of capital. Thus, accounting earnings is not consistent predictor of firms' value and cannot be used for to measuring corporate performance (Sharma and Kumar 2010). Today, the true measure of corporate performance is Economic Value Added (EVA). It is not just a measure but an integrated management philosophy. In last few years EVA has become the most accurate measure of shareholder value creation around the world. Therefore, the Economic Value Added (EVA) is one of main evaluation criteria of companies' commitment with the shareholder value maximization objective. The real key to create shareholders' wealth is that a business enterprise has to earn economic returns to its owners for its economic survival (Kaur and Narang 2010). This study explores the extent of EVA disclosure practices of Sri Lankan listed companies and application of EVA metrics in the variety of corporate decision making. This research is organized as follows. Next section discusses the concept of economic value added, calculation and relationship to Capital Asset Pricing model (CAPM). Section 3 reviews the literature and stated the derived hypothesis for the study. Section 4 describes the methodology adopted. Section 5 presents analysis and interpretation and section 6 concludes the research.

\section{Concept of Economic Value Added, Calculation and Relationship to Capital Asset Pricing Model (CAPM)}

Concept of EVA is originated on the article 'Dividend Policy Growth and the Valuation of Shares' (Modigliani and Merton 1961). The ideas of free cash flow and the evaluation of business on a cash basis developed by them were extended into the concept of the EVA by Stewart and Stern (1991). They asserted that EVA was the optimal performance metric most directly linked to the creation of shareholder wealth over time (Stewart 1997). EVA is an estimate of true economic profit, or the amount by which earnings exceed or fall short of the required minimum rate of return investors could get by investing in other securities of comparable risk (Stewart 1990). The most continuous error financial professionals are presently making is that treating the equity capital as free of cost. Further, there is a criticism that the traditional performance measurement tools have not presented the real shareholder value of the company. Therefore the Stern Stewart maintains the implementation of a complete EVA based financial management and incentive compensation system that gives managers both better information and superior motivation to make decisions that will create the maximum shareholder wealth in any publicly owned or private owned organizations. Therefore, Economic Value Added (EVA) is one measurement that can realistically measures the economic contribution of a company. EVA can be simply defined as an economic over profit that remains to the equity holders after considering all economic cost.

EVA is the surplus left after making an appropriate charge for the capital employed in the business (Kumar and Sharma 2010). According to the previous literature, number of adjustments required to reach economic profit and economic capital. Stern-Stewart and company have suggested 164 accounting adjustments to convert the profit which is based on the generally accepted accounting principles to reach economic profit (Stewart 1997). Calculating of weighted average cost of capital and then converting into economic capital is another important point. Weaver (2001) found that cost of equity capital is calculating using capital assets pricing model (CAPM). The following formula used to calculate EVA.

$$
\mathrm{EVA}=\mathrm{NOPAT}-(\mathrm{TCE} \times \mathrm{WACC})
$$

Where NOPAT is net operating profit after tax, TCE is total capital employed and WACC is weighted average cost of capital. While calculation of NOPAT, the non-operating items like dividend/interest on securities invested outside the business, non-operating expenses etc. will not be considered. The total capital employed is the sum of shareholders funds as well as loan not be considered. However this does not include investments outside the business. In determining the WACC, cost of debt is taken as after tax cost and cost of equity is measured on the basis of CAPM method. This indicates that a measure of profitability takes into consideration the cost of total invested equity and provides an accurate indication of true economic value generated by the company as oppose to accounting profits. Therefore, CAPM enters into the discussion. According to the CAPM cost of equity is calculated as follows; $\mathrm{Ke}=\mathrm{Rf}+$ bi (Rm- Rf), Where, $\mathrm{Rf}$ is Risk free return, $\mathrm{Rm}$ is Expected market rate of return, $\mathrm{Bi}$ is Risk coefficient of particular investment (Market Risk) and therefore, The cost of capital is most important aspect of EVA calculation. Many leading companies all over the world motivated to apply the EVA statement due to the relationship between EVA and the share holders' wealth. Companies can reap the benefits in terms of shareholder wealth maximization by using EVA performance measurement tool by linking with decision making, organizational incentive plans and firm's performance evaluation system.

\section{Literature Review}

Economic Value Added (EVA) is a measure of economic profit (Stewart 1991). It is calculated as the difference between the Net Operating Profit after Tax and the opportunity cost of 
invested Capital. This opportunity cost is determined by the weighted average cost of debt and equity capital (WACC) and the amount of capital employed. There is an equivalent way to calculate EVA, i.e. multiply capital by the difference between the Return on Capital and the WACC. EVA is the soundest performance metric. Furthermore it is closely relating with the creation of shareholder value. According to the previous researchers, many researches argue that EVA is a better decision tool than NPV because it captures the period by period value creation or destruction of a given firm or investment, and makes it easy to audit performance against management projections. Next section of the reviews the literature for comparison between EVA and traditional financial performance measures.

Previous researchers mainly focus on the comparison between traditional performance measurements with that the value based measures. Popa-Lala (2010) find that to achieve overall performance of an enterprise, indicators such as return on investment, residual income and EVA are more suitable than the profitability of sales because value based performance take in to consideration both profits of the firm and the investment of the firm. Pohlen and Goldsby (2003) provided an extension to the EVA analysis at the process level provides a linkage from individual performance to shareholder value. Austin (2005) tested about the adoption of EVA income as a benchmark for setting pricing and other policies of a monopolistic state-owned enterprise in the absence of normal benchmarking mechanisms. Palliam (2006), explored that the EVA is more highly associated with stock returns and firm values than accrual earnings. Mittal, Singha and Singh (2008) investigated the linkage between EVA and the corporate responsibility. Wet and Hall (2004) investigated that the relationship between the EVA, MVA and Leverage and they found that the size of the total level of leverage including EVA is determined by all three elements causing the leverage. Kumar and Sharma (2011) tested that association of EVA and accounting earnings with market value and the empirical results of the study do not support the claim that EVA is a better performance indicator than traditional accounting measures in explaining market value. Kumar and Sharma (2011), found that NOAPT and OCF outperform EVA in explaining the market value of Indian companies they explained that EVA makes a marginal contribution to information content beyond traditional performance measures such as NOPAT, OCF, EPS and RONW etc... However, this study was unable to prove that EVA is superior than the traditional accounting based measures in association with market value of the firm. Ramana (2009), discussed the implementation of EVA financial management system at Godrej Consumer Products Ltd the leading FMCG Company in India. The study highlighted the motivations, benefits, mechanics, limitations and issues in implementing EVA.

Next the study reviews the importance of the EVA implementation. Ghani (2005) discussed about the essential of the EVA disclosure because the market participants use this information to assess a company's future potential. He found that significant number of USA firms is adopting EVA as an integral part of their value management system. The study also suggested that along with the EVA disclosure, company should also report their cost of equity capital to reduce the valuation error when it is estimated by the investors themselves. Dodd and Johns (1999) surveyed the EVA adopters and EVA non adopters in corporate sector in USA. They believe that, EVA result describes the short term economic development of a company.

Kaur and Narang (2010) explored the degree of EVA disclosure made by Indian largest 500 companies in their annual reports. They found that 90 percent of Indian largest companies were not included EVA disclosures in their published annual reports. Sangameshwaran (2002) explored that the primary objective of the EVA implementation is association of shareholder interest with that of the employees. It reveals that how the shareholders "goal of value creation is linked to their employees" performance incentives. Companies are making voluntary disclosures for improved transparency Dhamija (2008). Traditional measures like ROCE, RONW, EPS, growth in EPS do not reflect the real value of shareholders wealth and thus EVA has to be measured scientifically to have a real idea about shareholders value.

Kaur and Narang (2008) reviewed the issues of EVA reporting practices they find that 37 companies specifically mentioned the use of EVA netric in their disclosures. Ghani (2005) explored EVA reporting practices of U.S. firms and they used EVA as a performance evaluation and compensation tool and made available as public disclosures. A higher proportion of firms use EVA to design their bonus and option plans.

According to the literature reviewed above revealed that most of the researchers focused on the comparison of traditional measures of financial performance with the value based measures and examine the relationship between EVA and stock prices or returns. Therefore, there was no single research addressed the EVA reporting practices of listed companies in Sri Lanka. Therefore, this study explores the extent of EVA disclosure practices in the annual reports of Sri Lankan listed companies and corporate attributes associated with the Sri Lankan corporate sector on EVA disclosure choices.

Therefore, the objective of this research is twofold. Firstly, research focuses on duration, industry composition and residential status, medium of communication, application of EVA metrics and the firm specific attributes that are associated with companies' choice of EVA disclosure. Secondly, study attempted to compare EVA reporting and non reporting companies on the basis of various attributes, the study further concerned with the identification of factors significantly influence on the decision of using EVA and its disclosures in annual reports. Consequently for the purpose of achieving second objective, study derived following hypothesis (Kaur and Narang 2010):

$\mathrm{H}_{1}=$ EVA reporting companies are not significantly different from EVA non reporting companies in terms of their age, residential status, profitability, leverage, sales efficiency and earnings potential. 


\section{Methodology}

This study revolves around firm specific information and therefore makes use of 85 Sri Lankan companies listed in the Colombo Stock Exchange as at 2013 on the basis of company size measured in terms of market capitalization. To examine the degree of EVA reporting practices among selected companies, annual reports of each company were thoroughly examined for the financial years from 2009 to 2013.

The study at first applies different tabulations and classifications to identify the extent of EVA disclosures of reporting companies (Kaur and Narag 2010). For this specific identification researcher used industry affiliations, residential status, and medium (source of disclosure) and area of EVA applicability as characteristics. Further, univariate analysis was applied to analyze the difference between the performance of EVA reporting and non reporting companies. In this respect study used t-test to assess the statistical significance of the difference between two independent sample means.

The second major step of the study was to compare the differences between EVA reporting and EVA non-reporting companies on the basis of their background indicators and financial performance measures. The corporate financial performance of the two groups has been compared on the basis of size, profitability, sales efficiency, leverage and earnings potential. The parameters used to analyze the background indicators are age and residential status of the companies in each group. The study attempted to identify whether there is any impact of EVA usage and EVA disclosure choice of the Sri Lankan listed companies are depend on the company background indicators and the company financial performance measures. To achieve the second objective two independent sample t-test was used.

\section{Analysis and Interpretation}

Next section presents the extent of EVA reporting practices and disclosure choice of Sri Lankan listed companies.

\subsection{Extent of EVA Reporting Practices in Sri Lankan Listed Companies}

EVA disclosure is not a mandatory requirement for the Sri Lankan listed companies. A list of EVA disclosure reporting companies has been developed by thorough examinations of each company's annual report over 85 listed companies. There were only fifteen listed companies which specifically disclosed EVA statement in their annual reports. These EVA statements they have used as a indicator of measuring financial performance of the company and eventually used for decision making. Table 1 provides the name, industry affiliation, residential status, medium of EVA disclosure and EVA application specific to each company.

Table 1. EVA Reporting Listed Companies and Their Respective Industry Affiliation, Residential Status, Medium of EVA Disclosure and EVA Application.

\begin{tabular}{|c|c|c|c|c|c|}
\hline $\begin{array}{l}\text { Serial } \\
\text { Number }\end{array}$ & Company Name & Industry & $\begin{array}{l}\text { Resident } \\
\text { ial } \\
\text { Status }\end{array}$ & Medium/Source of Disclosure & EVA Application \\
\hline 1 & John Keells Holdings Plc & Diversified Holdings & MNE & $\begin{array}{l}\text { Sustainability integration \& } \\
\text { risk management and Financial } \\
\text { highlights }\end{array}$ & Performance measurement \\
\hline 2 & Commercial Bank Of Ceylon Plc & $\begin{array}{l}\text { Bank Finance and } \\
\text { Insurance }\end{array}$ & MNE & Sustainability Supplement & Performance measurement \\
\hline 4 & Dialog Axiata Plc & Telecommunications & MNE & Shareholders' information & Performance measurement \\
\hline 5 & Sampath Bank Plc & $\begin{array}{l}\text { Bank Finance and } \\
\text { Insurance }\end{array}$ & Local & $\begin{array}{l}\text { Supplementary information } \\
\text { separate section }\end{array}$ & Performance measurement \\
\hline 6 & Aitken Spence Hotel Holdings Plc & Hotels and Travels & MNE & $\begin{array}{l}\text { Integrated Management } \\
\text { Discussion and analysis }\end{array}$ & Performance measurement \\
\hline 7 & National Development Bank Plc & $\begin{array}{l}\text { Bank Finance and } \\
\text { Insurance }\end{array}$ & Local & Sustainability report & Economic performance \\
\hline 8 & People's Leasing \& Finance Plc & $\begin{array}{l}\text { Bank Finance and } \\
\text { Insurance }\end{array}$ & Local & $\begin{array}{l}\text { Key performance indicators } \\
\text { and shareholder information }\end{array}$ & Performance measurement \\
\hline 9 & Asiri Hospital Holdings Plc & Health Care & Local & $\begin{array}{l}\text { Economic Value added } \\
\text { separate section }\end{array}$ & Performance measurement \\
\hline 10 & Seylan Bank Plc & $\begin{array}{l}\text { Bank Finance and } \\
\text { Insurance }\end{array}$ & Local & Sustainability report & Performance measurement \\
\hline 11 & LB Finance Plc & $\begin{array}{l}\text { Bank Finance and } \\
\text { Insurance }\end{array}$ & Local & Sustainability report & Performance measurement \\
\hline 12 & Brown \& Company Plc & Trading & MNE & Financial Highlights & Performance measurement \\
\hline 13 & $\begin{array}{l}\text { Mercantile Investments and Finance } \\
\text { Plc }\end{array}$ & $\begin{array}{l}\text { Bank Finance and } \\
\text { Insurance }\end{array}$ & Local & $\begin{array}{l}\text { Economic Value added } \\
\text { separate section }\end{array}$ & Performance measurement \\
\hline 14 & Diesel \& Motor Engineering Plc & Motors & MNE & Financial Highlights & Performance measurement \\
\hline 15 & Asiri Surgical Hospital Plc & Health Care & Local & $\begin{array}{l}\text { Economic Value added } \\
\text { separate section }\end{array}$ & Performance measurement \\
\hline
\end{tabular}


It reveals that listed companies which have adopted EVA in study period were represented several industries. Out of 15 EVA reporting companies, seven listed companies coming under the Bank, Finance and Insurance segment $(46.7 \%$ of the sample). For example Commercial Bank of Ceylon PLC, Sampath Bank Plc, National Development Bank Plc, People's Leasing and finance Plc, Seylan Bank Plc, LB Finance Plc and Mercantile Investments and Finance Plc. Further two companies (13.37\%) coming under the Health Care Industry. Single company is represented from following industries i.e. Diversified Holdings, Oil Palms, Telecommunication, Hotel and Travelling, Trading and Motors segment. Table 1 reveals that out of EVA reporting listed companies eight companies $(60 \%)$ are engage in business locally and seven (46.67\%) companies operating overseas.

\subsection{Medium of Disclosure}

Table 2 shows the medium of EVA disclosure used by the Sri Lankan listed companies when the report EVA statements in their annual reports.

Table 2. Medium of Disclosure Used for EVA Reporting Listed Companies.

\begin{tabular}{lll}
\hline Medium of Disclosure Used & Number of Companies & Percentage \% \\
\hline Management discussion & 1 & 6.67 \\
Separate Section & 4 & 26.67 \\
Sustainability Report & 4 & 26.67 \\
$\begin{array}{l}\text { Additional Information } \\
\text { Shareholders to }\end{array}$ & 2 & 13.33 \\
Financial Highlights & 2 & 13.33 \\
More than one & 2 & 13.33 \\
Total & 15 & 100.00 \\
\hline
\end{tabular}

It is observed that various medium used by Sri Lankan listed companies to disclose EVA statement in their annual reports. Four companies (26.67\%), reporting their EVA statements as separate section and next four listed companies included EVA statement in sustainability report. The companies who were reported EVA performance as separate section in their annual reports are Sampath Bank PLC, Asiri Hospital Holding PLC, Mercantile Investments and Finance PLC and Asiri Surgical Hoapital PLC. Commercial Bank of Ceylon PLC, National Development Bank PLC, Seylan Bank PLC and LB Finance PLC have been included EVA statements in sustainability report. Bukit Darah PLC and Dialog Axiata PLC reported EVA within the section of additional information to shareholders (13.33\%). The John Keells Holdings PLC and Peoples's Leasing \& Finance PLC were included their EVA statements more than one sections in their annual reports. The Aitken Spence Hotels Holdings PLC was included their EVA performance under the management discussion and analysis section. At the same time it is important to mention that EVA reporting companies use measures in combination with the traditional performance measures such as Profits, ROI, EPS, ROCE etc. This indicates that the companies those who are reporting EVA performance have not be dropped the use of the long established accrual accounting based measures after adopting EVA. EVA disclosure is not mandatory to the Sri Lankan listed companies. It is observed that the stakeholders like investors, shareholders, borrowing institutions and stock market wish to have traditional performance measures than the value based performance measure EVA in their published annual reports.

\subsection{Areas of EVA Application}

Table 3 shows the usage of EVA in Sri Lankan listed companies. The study explored that all EVA reporting companies are using the EVA measures for the evaluation of business and financial performance of companies. The results suggest that the motivation behind the EVA calculation and reporting by Sri Lankan listed companies is to measure the true economic performance of the firm.

Table 3. Areas of EVA Application in Sri Lankan Listed Companies.

\begin{tabular}{lll}
\hline Scope of Use & Number of Companies & Percentage \\
\hline $\begin{array}{l}\text { Business/Financial Performance } \\
\text { Measurement }\end{array}$ & 15 & 100 \\
$\begin{array}{l}\text { Shareholder Value Enhancement } \\
\text { Incentive Payments/Equitable }\end{array}$ & 0 & 0 \\
$\begin{array}{l}\text { Reward System } \\
\text { Setting Targets }\end{array}$ & 0 & 0 \\
\hline
\end{tabular}

(Source: Annual Reports of 2009/2013 of the EVA Reporting Listed Companies)

\subsection{Company Wise EVA Disclosures in Sri Lankan Listed Companies}

Table 4 shows that company wise extent of EVA disclosure in Sri Lankan listed companies. It is reported that number of years each company reported EVA statement in annual report of 2009/2013. Table 4 shows that four companies such as Commercial Bank of Ceylon Plc, Sampath Bank Plc, Aitken Spence Hotels Holdings Plc and Seylan Bank Plc were reported five years EVA figures in their annual report of 2011. Dialog Axiata Plc was reported 4 years EVA figures in their annual report of 2009/2012.

Further the study categorized that the EVA statements in two types, such as basic statement and EVA statement with Adjustments. Basic statement means that those companies' EVA statement provide EVA calculation without making any GAAP based accounting adjustments to the net operating profit after tax (NOPAT) as per the income statement or Capital employed in the balance sheet. The second category is EVA statement with adjustment. This includes those companies which have made at least one relevant accounting adjustment when computing EVA. 
Table 错误! 文档中没有指定样式的文字。. Company Wise Extent of EVA Disclosure in Sri Lankan Listed Companies.

\begin{tabular}{|c|c|c|c|c|c|c|}
\hline \multirow{2}{*}{ Company Name } & \multirow{2}{*}{ Number of Years EVA Reporting } & \multirow{2}{*}{ EVA In Rs. } & \multirow{2}{*}{ EVA Ratio } & \multicolumn{3}{|c|}{ EVA statement } \\
\hline & & & & Basic & With Adjustments & CAPM Based Ke \\
\hline John Keells Holdings Plc & 3 years & $\sqrt{ }$ & $x$ & $\sqrt{ }$ & $\times$ & Not mentioned \\
\hline Commercial Bank of Ceylon Plc & 5 years & $\sqrt{ }$ & $x$ & $\sqrt{ }$ & 3 Adjustments & $\sqrt{ }$ \\
\hline The Bukit Darah Plc & 2 years & $\sqrt{ }$ & $\times$ & $\sqrt{ }$ & $x$ & Not mentioned \\
\hline Dialog Axiata Plc & 4 years & $\sqrt{ }$ & $\times$ & $\sqrt{ }$ & $\times$ & Not mentioned \\
\hline Sampath Bank Plc & 5 years & $\sqrt{ }$ & $\times$ & $\sqrt{ }$ & 3 adjustments & Economic cost \\
\hline Aitken Spence Hotel Holdings Plc & 5 years & $\sqrt{ }$ & $x$ & $\sqrt{ }$ & 3 adjustments & $\sqrt{ }$ \\
\hline People's Leasing \& Finance Plc & 3 years & $\sqrt{ }$ & $\times$ & $\sqrt{ }$ & 3 Adjustments & Economic cost \\
\hline Asiri Hospital Holdings Plc & 2 years & $\sqrt{ }$ & $\times$ & $\sqrt{ }$ & $x$ & Not mentioned \\
\hline Seylan Bank Plc & 5 years & $\sqrt{ }$ & $\times$ & $\sqrt{ }$ & 3 Adjustments & Economic cost \\
\hline LB Finance Plc & 2 years & $\sqrt{ }$ & $\times$ & $\sqrt{ }$ & 3 Adjustments & Economic cost \\
\hline Brown \& Company Plc & 2 years & $\sqrt{ }$ & $x$ & $\sqrt{ }$ & $\times$ & Not mentioned \\
\hline Mercantile Investments and Finance Plc & 2 years & $\sqrt{ }$ & $x$ & $\sqrt{ }$ & 2 Adjustments & Economic cost \\
\hline Diesel \& Motor Engineering Plc & 2 years & $\sqrt{ }$ & $\times$ & $\sqrt{ }$ & 1 adjustment & $\sqrt{ }$ \\
\hline
\end{tabular}

(Source: Annual Reports of 2009/2013 of the EVA Reporting Listed Companies)

Notes: $\sqrt{ }$ indicates reported and $\times$ indicates not reported.

Table 4 shows that, 10 companies were incorporated required adjustments in their EVA computation. Those are Commercial Bank of Ceylon Plc, Sampath Bank Plc, Aitken Spence Hotel Holdings Plc, National Development Bank Plc, People's Leasing \& Finance Plc, Seylan Bank Plc, LB Finance Plc, Mercantile Investments and Finance Plc, Diesel \& Motor Engineering Plc and Asiri Surgical Hospital Plc.

In addition to that Table 4 tries to explore whether the EVA reporting companies calculated their cost of equity capital by adopting CAPM method or not. The study explored that three companies used CAPM to derive cost of equity capital. Those companies are Commercial Bank of Ceylon Plc, Aitken Spence Hotel Holdings Plc and Diesel \& Motor Engineering Plc. Furthermore Table 4 shows that, the five companies were used economic cost (Treasury bill rate + fixed percentage) as cost of equity while computing EVA. Seven companies were not mentioned the method they have used for calculate cost of equity.

\subsection{Industry Wise Classification of EVA Reporting Companies}

The maximum number of companies (46.67) was reporting EVA from Banking, Finance and Insurance sector. Those companies are Commercial Bank of Ceylon Plc, Sampath Bank Plc, National Development Bank Plc, People's Leasing \& Finance Plc, Seylan Bank Plc, LB Finance Plc and Mercantile Investments and Finance Plc. Two companies belong to health care industry. It is important to mention that majority of EVA reporting companies are representing the Banking, Finance and Insurance sector.

Table 4. Industry Wise Classification of EVA Reporting Companies.

\begin{tabular}{lll}
\hline Industry & $\begin{array}{l}\text { Number of } \\
\text { Companies }\end{array}$ & Percentage \\
\hline Diversified Holdings & 1 & 6.67 \\
Bank Finance and Insurance & 7 & 46.67 \\
Oil Palms & 1 & 6.67 \\
Telecommunication & 1 & 6.67 \\
Hotels and Travels & 1 & 6.67 \\
Health Care & 2 & 13.33 \\
Trading & 1 & 6.67 \\
Motors & 1 & 6.67 \\
Total & 15 & 100.00 \\
\hline
\end{tabular}

(Source: Annual Reports of 2009/2013 of the EVA Reporting Listed Companies)

\subsection{EVA Disclosure (Aggregate) by Sri Lankan Sri Lankan Listed Companies}

Table 6 presents that the extent of EVA disclosures in terms aggregates. It reveals that 20 percent of EVA user companies calculating cost of equity based on the CAPM method. All the EVA reporting companies showed EVA figures in Rupees in their annual reports. Among EVA reporting companies 33.33 percent (5 listed companies) provides basic EVA statements. Majority among EVA reporting companies 66.67 percent (10 companies) were at least one economic value based accounting adjustment while computing EVA measure.

Table 5. Extent of EVA Disclosure Sri Lankan Listed Companies.

\begin{tabular}{lllll}
\hline Particulars & Number of EVA reporting Companies & Percentage & Number of EVA non reporting Companies & Percentage \\
\hline CAPM based Cost of Equity Calculation & 3 & 20 & 12 & 80 \\
EVA (in Rs.) & 15 & 100 & 0 & 0 \\
EVA Ratio & 0 & 0 & 15 & 10 \\
EVA Statement Basic & 5 & 33.33 & 10 \\
EVA Statement with Adjustments & 10 & 66.67 & 5 \\
\hline
\end{tabular}

(Source: Annual Reports of 2009/2013 of the EVA Reporting Listed Companies.) 
The first part of the study explored that the medium and extent of EVA computations made and disclosed by the EVA reporting Sri Lankan listed companies. This section disclosed that the significant inconsistencies and irregularities in calculation of EVA and its considerable items such as cost of equity capital in Sri Lankan listed companies. The main reason behind this might be most of the companies reluctant to change the traditional accounting system and performance measurements because after adjusting the relevant adjustment to the NOPAT, the notional profit can changed. However first part of this study is to ensure a more meaningful and realistic use of financial statements and information provided by the company.

Next section explores the certain corporate attributes that can be influenced on EVA disclosure choice of companies.

\subsection{Factors Affecting the Sri Lankan Companies' to decide EVA Disclosure Choice}

Mathematical construct of EVA ensures that those companies are trying to optimize sales revenue, cost of capital, ROCE and net operating profits (Deubby 2000). Ehrbar (1999) found that number of US companies have shown exceptional strong performance when they switched to EVA. The second objective of the study is to explore the certain corporate attributes that can be influence to the companies EVA disclosure choice. It is predicted that few background variable and the company financial performance measures can be associated with the companies EVA application and the disclosure of their annual reports. Therefore, EVA reporting EVA non reporting companies compared on the basis of five company financial performance measures such as profitability, company size, leverage, sales efficiency and earnings potential and two background indicators such as company age and residential status. The objective of this investigation is to examine that whether the difference between two samples such as EVA reporting companies and EVA non reporting companies are statistically significant or not in terms of the selected measures.

Profitability differences of EVA reporting and non reporting companies have been investigated by using Return on Total Assets (ROTA) and Return on Equity (ROE) and presented in table 7 .

Table 7. Comparison between EVA reporting and EVA non-reporting companies on the basis of profitability.

\begin{tabular}{llllllllll}
\hline \multicolumn{7}{c}{ ROTA $(\%)$} & \multicolumn{5}{c}{ ROE (\%) } \\
\hline Year & NR & R & Mean-NR & Mean-R & t-stat & Mean-NR & Mean-R & t-stat \\
\hline 2009 & 70 & 15 & 15.674 & 9.615 & $-2.221^{*}(0.001)$ & 15.003 & 22.485 & $-3.052^{*}(0.001)$ \\
2010 & 70 & 15 & 15.465 & 9.814 & $-2.965^{*}(0.002)$ & 16.526 & 23.562 & $-2.754^{*}(0.005)$ \\
2011 & 68 & 17 & 14.320 & 10.632 & $-2.154^{* *}(0.014)$ & 17.125 & 23.854 & $-1.248(0.314)$ \\
2012 & 70 & 20 & 13.535 & 11.02 & $-2.188^{*}(0.002)$ & 18.951 & 21.412 & $-2.256^{*}(0.004)$ \\
2013 & 72 & 20 & 13.412 & 10.96 & $-2.488^{*}(0.005)$ & 16.872 & 19.253 & $-1.412(0.258)$ \\
\hline
\end{tabular}

NR: No of observations of EVA non-reporting companies, N: No of observations of EVA reporting companies. * means significant at $1 \%$ level and ** means significant at $5 \%$ level.

The results are in favour of EVA reporting companies which shows that companies which are more profitable tend to disclose their EVA statement more than the companies with lower profitable category in their operations and therefore results reject the null hypothesis of no difference between two groups. In this respect agency theory suggest that managers of larger companies wish to obtain personal advantages like continuation of managerial position and compensation (Inchausti 1997).

\subsection{Comparison Between EVA Reporting and EVA Non- Reporting Companies in Terms of Size}

Company size has been considered as a major factor that can have influence on the company's EVA disclosure decision. Large companies attract attention of regulatory agencies and as a result of that there is a discernible disclosure of information to stakeholders. On the other hand large companies are more visible in an economy due to various reasons. Table 8 reports size variables selected for the analysis of EVA reporting and non-reporting companies. Company size measured in terms of total market capitalization, total assets and total sales.

By observing the mean values of two groups of companies EVA reporting companies are much larger than EVA non reporting companies. This difference is found to be statistically significant in terms of total market capitalization and total sales value by rejecting the hypothesis of no difference of size between two groups of companies. These findings imply that large Sri Lankan firms are more likely to disclose EVA related information in their annual reports than smaller ones in terms of market capitalization. In contrary to this total asset despite the difference exist in two groups it is not found to be statistically significant. 
Table 8. Comparison between EVA Reporting and EVA Non-reporting Companies in terms of size.

\begin{tabular}{|c|c|c|c|c|c|c|c|c|c|c|c|}
\hline \multirow[b]{2}{*}{ Year } & \multicolumn{5}{|c|}{ TMCAP (in Rs.'000) } & \multicolumn{3}{|c|}{ Total Assets (in Rs.'000) } & \multicolumn{3}{|c|}{ Total sales (in Rs.'000) } \\
\hline & NR & $\mathbf{R}$ & Mean-NR & Mean-R & t-stat & Mean-NR & Mean-R & t-stat & Mean-NR & Mean-R & t-stat \\
\hline 2009 & 70 & 15 & 10.314 & 32.245 & $\begin{array}{l}-2.121 * \\
(0.001)\end{array}$ & 16.253 & 22.485 & $\begin{array}{l}-.258 \\
(0.551)\end{array}$ & 12.23 & 15.56 & $\begin{array}{l}-1.255 \\
(0.047)^{* * *}\end{array}$ \\
\hline 2010 & 70 & 15 & 13.725 & 33.458 & $\begin{array}{l}-2.125 * \\
(0.002)\end{array}$ & 18.411 & 21.562 & $\begin{array}{l}-.754 \\
(0.725)\end{array}$ & 13.45 & 23.85 & $\begin{array}{l}-2.568 \\
(0.021)^{* *}\end{array}$ \\
\hline 2011 & 70 & 15 & 23.435 & 35.212 & $\begin{array}{l}-2.154 * * \\
(0.041)\end{array}$ & 21.255 & 23.321 & $\begin{array}{l}-.237 \\
(0.314)\end{array}$ & 15.58 & 44.96 & $\begin{array}{l}-3.569 * \\
(0.021)\end{array}$ \\
\hline 2012 & 70 & 15 & 31.125 & 42.369 & $\begin{array}{l}-2.188 * \\
(0.032)\end{array}$ & 23.887 & 24.458 & $\begin{array}{l}-.256 \\
(0.554)\end{array}$ & 18.25 & 48.25 & $\begin{array}{l}-2.258^{* *} \\
(0.023)\end{array}$ \\
\hline 2013 & 70 & 15 & 44.254 & 62.145 & $\begin{array}{l}-2.488 * \\
(0.005)\end{array}$ & 25.952 & 31.258 & $\begin{array}{l}-.412 \\
(0.698)\end{array}$ & 23.58 & 52.26 & $\begin{array}{l}-1.987 * * \\
(0.482)\end{array}$ \\
\hline
\end{tabular}

NR: Non-reporting companies. R: no. of observations for EVA reporting companies. *means significant at !\% level; ** means significant at $5 \%$ level and $* * *$ means significant at $10 \%$ level.

\subsection{Comparison Between EVA Reporting and EVA Non- Reporting Companies in Terms of Leverage, Sales Efficiency and Earnings Potential}

Debt holders concern about their interest and loan recovery and transparency of company matters towards them help dominant creditors to monitor the course of their investment. Hence to indentify whether high debt provides an incentive to Sri Lankan companies to disclose nonmandatory EVA computations in their annual reports, the study picked financial leverage as a significant variable of comparison between the EVA reporting and non-reporting companies. Leverage has been defined as the ratio of the book value of debt over the book value of equity. Table 9 reports that the significant difference exists between EVA reporting and non reporting companies on the basis of leverage.

Sales efficiency of a company is represented by its ratio of sales as percentage of the total assets which indicates how intensively the total assets are used in production (Guerard 2005) and then to sales. This indicator distinguishes between efficient and inefficient companies. Analysis reveals that higher sales efficiency belongs to the EVA reporting companies and vice-versa. This difference is found to be statistically significant, and therefore rejecting the null hypothesis of no difference between the two groups based on their sales efficiency. Table 9 again compares the performance of EVA reporting companies with EVA nonreporting companies on the basis of EPS. The economic performance of a company is better judged in terms of EPS because, it is one of major factors affecting dividend policy and the market price of the company shares. Results reveals that mean value of two groups are different and statically insignificant and therefore accepting the null hypothesis that no difference between EVA user and EVA non user companies on the basis of earning potential.

Table 9. Compares the performance of EVA reporting and non-reporting companies on the basis of leverage, sales efficiency and earnings potential.

\begin{tabular}{|c|c|c|c|c|c|c|c|c|c|c|c|}
\hline \multirow[b]{2}{*}{ Year } & \multirow[b]{2}{*}{ NR } & \multirow[b]{2}{*}{$\mathbf{R}$} & \multicolumn{3}{|c|}{ Leverage (in times) } & \multicolumn{3}{|c|}{ Sales efficiency (in Rs.'000) } & \multicolumn{3}{|c|}{ Earnings potential (in EPS) } \\
\hline & & & Mean-NR & Mean-R & t-stat & Mean-NR & Mean-R & t-stat & Mean-NR & Mean-R & t-stat \\
\hline 2009 & 70 & 15 & 0.3910 & 0.9261 & $\begin{array}{l}2.768 * \\
(0.001)\end{array}$ & 87.399 & 41.756 & $\begin{array}{l}-1.258 * * * \\
(0.053)\end{array}$ & 12.715 & 34.566 & $\begin{array}{l}-0.255 \\
(0.433)\end{array}$ \\
\hline 2010 & 70 & 15 & 0.3458 & 0.9352 & $\begin{array}{l}2.654 * \\
(0.002)\end{array}$ & 86.314 & 41.438 & $\begin{array}{l}-1.754 \\
(0.725)\end{array}$ & 13.45 & 33.859 & $\begin{array}{l}-0.568 \\
(0.699)\end{array}$ \\
\hline 2011 & 70 & 15 & 0.3524 & 0.9005 & $\begin{array}{l}-1.698 * * \\
(0.041)\end{array}$ & 89.455 & 41.879 & $\begin{array}{l}-1.237 * * \\
(0.025)\end{array}$ & 15.58 & 34.962 & $\begin{array}{l}-0.569 \\
(0.855)\end{array}$ \\
\hline 2012 & 70 & 15 & 0.3561 & 0.8998 & $\begin{array}{l}2.188 * \\
(0.032)\end{array}$ & 87.587 & 40.716 & $\begin{array}{l}-1.256^{*} \\
(0.008)\end{array}$ & 18.25 & 33.785 & $\begin{array}{l}-0.258 \\
(0.287)\end{array}$ \\
\hline 2013 & 70 & 15 & 0.3969 & 0.9195 & $\begin{array}{l}1.448 * \\
(0.005)\end{array}$ & 86.498 & 41.331 & $\begin{array}{l}-1.412 * * \\
(0.027)\end{array}$ & 23.58 & 34.586 & $\begin{array}{l}-0.987 \\
(0.482)\end{array}$ \\
\hline
\end{tabular}

NR- EVA non-reporting and $\mathrm{R}$ is EVA reporting companies. * means significant at $1 \%$ level and ** means significant at $5 \%$ level.

\subsection{Comparison of EVA Reporting and Non Reporting Companies on the Basis of Age and Residential Status}

Table 10 compares the difference between EVA Reporting and EVA Non-reporting companies on the basis of age and residential status. Because, older companies are more likely to have established and thereby their professional staff always like to deal with technical aspects of financial statements. As a result of that older companies are capable of producing more detailed information at lower cost compared to newly established companies (Shammari, 2008). The same table reports comparison between EVA and EVA non disclosure companies on the 
basis of residential status. The companies operating in overseas are subject to a broader range of regulatory issues and diverse in financing the business. Companies which exposed to rest of the world are expected to disclose more detailed information to adhere with the both parent and the host country. In connection with this Karim and Ahmed (2005) stated that these companies are usually equipped with more competent and efficient management and are more likely to have used advanced accounting systems and thereby forces to disclose more information without any additional costs. A dummy variable has been used distinguish domestic companies and multinational companies. Analysis revealed that two years (2011 and 2013) do not appear to be a significant factor to differentiate between EVA reporting and non reporting companies. Therefore, though important, the residential status of the companies is not found to be statiscally significant characteristic influencing their decision to disclose EVA in its annual reports.

Table 10. Compares the EVA reporting and non reporting companies on the basis of age and residential status.

\begin{tabular}{|c|c|c|c|c|c|c|c|c|}
\hline \multirow[b]{2}{*}{ Year } & \multirow[b]{2}{*}{ NR } & \multirow[b]{2}{*}{$\mathbf{R}$} & \multicolumn{2}{|c|}{ Age (in years) } & \multirow[b]{2}{*}{ t-stat } & \multicolumn{2}{|c|}{ Residential status } & \multirow[b]{2}{*}{ t-stat } \\
\hline & & & Mean-NR & Mean-R & & DOM & MDOM & \\
\hline 2009 & 70 & 15 & 49.757 & 53.200 & $0.320(0.687)$ & 0.0874 & 0.0784 & $-2.115^{* *}$ \\
\hline 2010 & 70 & 15 & 49.582 & 53.250 & $0.485(0.587)$ & 0.0804 & 0.0789 & $-2.113^{* *}$ \\
\hline 2011 & 70 & 15 & 51.687 & 54.589 & $0.885(-0.285)$ & 0.0805 & 0.0589 & -.1 .578 \\
\hline 2012 & 70 & 15 & 49.985 & 54.684 & $0.225(0.584)$ & 0.0853 & 0.0852 & $-1.852 * *$ \\
\hline 2013 & 70 & 15 & & 53.562 & $0.456(0.851)$ & 0.0799 & 0.0741 & -0.420 \\
\hline
\end{tabular}

DOM- proportion of domestic EVA reporting companies with total number of domestic in the sample and MDOM- proportion of multinational domestic companies with total number of multinational companies in the sample. * means that significant at $1 \%$ level of significance.

**means significant at $5 \%$ level.

The above analysis reveals that the decision regarding the EVA disclosures by Sri Lankan companies is influenced by firm's size, profitability, leverage, sales efficiency. On the other hand study finds that age and earnings potential do not have significant impact on the EVA disclosure choice of companies in Sri Lanka.

\section{Conclusion}

This research investigated the Economic Value Added disclosure practices of Sri Lankan listed companies. The first part of the study investigated the extent of EVA usage and disclosures done by Sri Lankan listed companies as per their published annual reports. Second part of the study explored that whether the EVA reporting listed companies are significantly different from EVA non reporting listed companies on the basis of financial performance indicators such as profitability, size, leverage, sales efficiency and earnings potential and company background indicators such as age and the residential status. The key findings of the study are on the basis of extent of EVA usage and disclosure made by Sri Lankan listed companies can be reported as follows; based on the basis of highest market capitalization, out of 85 listed companies only 15 companies were included the EVA disclosure in their published annual reports on the basis of business and financial performance measure. Around 82.35 percent of were not reported EVA statements in their published annual reports. Around 26.67 percent of the EVA reporting listed companies likely to use EVA statements in separate section and another 26.67 percent EVA reporting companies willing to be included EVA statement in sustainability report of their published annual reports. Around 46.67 percent EVA reporting companies are coming under the Bank, Finance and
Insurance industry sector. The traditional financial performance measures continued to use after the EVA implementation. Around 66.67 percent EVA disclosure companies were incorporated a few adjustments to the NOPAT and Economic Capital. Around 26.67 percent EVA reporting companies used CAPM model to calculate cost of equity. However, 7 companies (46.67 percent) were not disclosed the method used for calculation of cost of capital.

In addition to above this study finds that the EVA usage and disclosure choice in Sri Lankan listed companies is influenced by the company size, earnings potential and leverage. In this respect, profitability, sales efficiency, age and residential status were not significantly influenced on EVA disclosure choices of Sri Lankan companies.

However, due to non mandatory requirement stipulated by the Sri Lanka Accounting Standards (LKAS) and Sri Lanka Financial Reporting Standards (LKFRS) together with listing requirements stipulated by the Securities Exchange Commission of Sri Lanka companies were reluctant to disclose EVA information. These limitations overcome by making EVA disclosure as mandatory reporting requirement of annual reports in corporate sector in Sri Lanka. In addition to that it is important to introduce separate accounting standard for EVA calculation and reporting. In overall introduction of EVA to corporate reporting eventually lead to shareholder wealth maximization as well as boosting the employee moral once it will incorporate to compensation plans.

\section{References}

[1] Abdeen, A.m. and Haight G. T. (2002) A Fresh Look At Economic Value Added- Empirical Study Of The Fortune Five Hundred Companies: Applied Busness Reaserch. 
[2] Ahmed, K. and Nicholls, D. (1994) The impact of non financial company characteristics on mandatory disclosure compliance in developing countries: The case of Bangaladesh. The International Journal of Accounting.

[3] Andrikopoulos, A. and Diakidis, N. (2007) Financial reporting practices on the internet: The case of companies listed in the Cyprus tock exchange: available at SSRN: http://ssm.com/abstract=999183.

[4] Athanassakos, G. (2007) Value-based management, EVA and stock price performance in Canada: Management decision.

[5] Austin, L.M. (2005) Benchmarking to economic value added: the case study of Airways Corporation of New Zealand Limited: An international Journal.

[6] Kassim, Z. I. (2012). Board Process, Capital Structure Decisions and Company Performance. Management Science and Engineering .

[7] Barako, D.G, Hancock, P. and Izan, H. Y. (2006) Factors influencing voluntary corporate disclosure by Kenyan companies: Corporate Governance.

[8] Bardia, S.C. (2002) Economic Value Added Overall Consideration:The Economic Challenger.

[9] Bhattacharya, A.K. and Phani, B.V. (2000) Economic Value Added- A general perspective. Social science research network.

[10] Biddle, G.C., Bowen, R.M., and Wallace, J.S., (1998) Does EVA beat earnings? Evidence on associations with stock returns and firm values.

[11] Bolek, M., Kacprzyk, M., and Wolski, R. (2011) Cash converson cycle and liquidity ratios relatioship based on companies listed on WSE:Reaserch papaers Wroclaw university of economics

[12] Bolek, M., Kacprzyk, M., and Wolski, R. (2012) The relationship between economic value added and cash conversion cycle in companies listed on the WSE:efinanse:financial quarterly.

[13] Byrne, O. and Stephen, F. (1996) EVA and market Value: Journal of Applied Corporate Finance.

[14] Byrnes, N. and Henry, D. (2001) Confused about earnings. Business Week Online, http://www.businessweek.com.

[15] David Crowther, M. D. (1998). Evaluation Corporate Performance a critique of Economic Value Added: Accounting Research

[16] Dhamija, S. (2008) EVA reporting practices in the annual reports of Indian companies - a case study of Hindustan Uniliver Limited: The Accounting World .

[17] Dobrica, F. I. (2008) Shareholder value enhancing strategies empirical evidence on multinational corporations behaviour.

[18] Dodd J.L. and Jhons, J. (1999) EVA reconsidered: Business and Economic Review.

[19] Dubby, R. (2000) Understanding the real measure of performance: EVA, Business Today.

[20] Ehrbar, A. and Stewart, G. B. (1999) The EVA Revolution: Journal of Applied Corporate Finance.
[21] Ghani,W.I., Tezel, A., Ragan, J.M., and Stagliano, A.J. (2005) Disclosure of EVA use in corporate financial reports Descriptive analysis: Applied Business Research.

[22] Guerard,J.B. (2005) Corporate Fianacial Policy and R \& D management $-2^{\text {nd }}$ edition: John Wiley and Sons.

[23] Ion, P.A.C. (2010) Some aspects regarding the performance indicators used in the management of a company.

[24] Inchausti, B.G. (1997) The influence of company characteristics and accounting regulation on information disclosed by Spanish firms: European Accounting review.

[25] Ittner, C. and larcker, D. (1998) Innovation in performance management- Trends and research implications : Journal of management accounting research.

[26] Kaplan, R. (1992) Balance Score Card: Harvard Business Review.

[27] Karim, A.K.M.W and Ahmed, J.U. (2005) Determination of IAS disclosure compliance in emerging economies.

[28] Kaur, M. and Narang, S. (2008) Economic Value Added reporting and financial performance- A study of Satyam Computer Services Limited: Journal of Accounting Research

[29] Kaur, M., and Narang, S. (2010) EVA Disclosures in the annual reports of Indian companies- an empirical study: Global Business Review

[30] Kirsche, C. (2013) Economic Value Added-A detail walkthrough: Business economics investments and finance.

[31] Kishore, R. M. (2002) Financial Management, $3^{\text {rd }}$ edition India: Taxmann Publishers.

[32] Kondragunta, S. C. (2000) Winning with EVA: Business Today.

[33] Kumar, S. and Sharma A. K. (2011) Association of EVA and Accounting earnings with market value- evidence from India: Asia-Pacific Journal of Business Administration.

[34] Kumar, S. and Sharma A. K. (2011) Further evidence on relative and incremental information content of EVA and traditional performance measures from select Indian companies:Asia pacific jornal of business.

[35] Leong, K., Pagani, M. and Zaima, L.K. (2009). Portfolio strategies using EVA earnings ratio or book-to-market:Is one best?: review of accounting and finance

[36] Loth, R. . Investopedia. Retrieved 04 23, 2013, from http://www.invetopedia.com

[37] Mamum, A., Entebang, H. and Mansor, S. (2012) EVA as superior performamce measurement tool:Mordern Ecomomy

[38] Misra, A. and Kaur, K. (2004) Linkages between Economic Value Added and share prices: An empirical study of Indian corporate sector.

[39] Mittal, R.K., Sinha, N. and Sigh, A. (2008). An analysis of linkage between economic value added and corporate social responsibility:Management Decision.

[40] Modiglaini, F and Miller, M.H. (1961). Dividend policy, growth and the valuation of shares, The Journal of Business, Vol. xxxiv, No.4 
[41] Palliam, R. (2005) Estimate the cost of capital: Journal of Risk Finance.

[42] Palliam, R. (2006) Further evidence of the information content of Economic Value Added: Review of accounting and Finance.

[43] Paulo, S. (2010) The UK Companies Act of 2006 and the Sarbanes-Oxley Act of 2002: Implications for EVA ${ }^{\circledR}$ (economic value added):International Journal of law and management.

[44] Pohlen, T.L. and Goldsby, T.J. (2003) How Economic Value Added can help sell the change: International Journal of Physical Distribution and Logistics Management.

[45] Rago, M. (2008) An Analysis of Econoic Value Added: senior papers.

[46] Ramana, V. (2009) EVA fnancial management at Godrej Consumer Products Limited: Social Science Research Network .

[47] Sangameshwaran, P. (2002) Courting EVA, the TCS way: Economic Value Added concepts and cases, pp. 177-84.

[48] Shammari, B.A. (2008) Voluntary disclosure in Kuwait corporate annual reports: review of business research

[49] Sharma, A. K. and Kumar, S. (2010) Economic Value Added (EVA) Literature Review and Relevant Issues. International Journal of Economics and Finance

[50] Sharma, S. (2005) Economic Value Added (EVA): Financial Analysts Journal
[51] Stewart, G.B. (1990) The quest for value- The management guide: Harper Business

[52] Stewart, G.B. (1991) The quest for value- A guide for senior managers: Harper Business

[53] Stewart, S. (1997) EVA for the oil and gas industry: Journal of Applied Corporate Finance.

[54] Vishwanath, R. (2009) EVA Financial Management at Godrej Consumer Products Ltd.

[55] Weaver, S.C. (2001) Measuring Economic Value Added- A Survey of the Practices of EVA Proponents. Applied Finance.

[56] Weissenrieder, F. (1998) Value Based Management: Economic Value Added or Cash Value Added: Papers.ssm.com.

[57] Wet, J.H. and Hall, J.H. (2004) The relationship between EVA, MVA and Leverage: Meditariaccountancy.

[58] Worthington, A.C. and West, T. (2001) Economic Value Added: A review of the theoritical and emperical liteture: Asian Review of Accounting .

[59] Young, D. (1997) Economic value Added- a premier for European managers: European management journal.

[60] Young, S.D. (1999) Some reflections on accounting adjustments and economic value added: Journal of financial statement analysis.

[61] Zimmerman, J.L. (1997) EVA and divisional performance measurement- capturing synergies and other issues: Journal of applied corporate finance. 